\title{
Need Analysis of MOOCs-Based Learning Media Development to Improve Student Motivation
}

\author{
Bukman Lian', Bebby Rino Oksatianti², Eko Risdianto3, Afrizal Mayub4
}

DOI: $10.35445 /$ alishlah.v13i2. 646

\begin{abstract}
Article Info
Abstract

Keywords:

Learning Media;

MOOCs;

Improving

Student Motivation;

Temperature and Heat

The development of MOOCs-based learning media is essential for increasing student motivation. This study aims to analyze the needs of developing MOOCsbased learning media to increase students' motivation on temperature and heat material. This type of research is survey research and literature study as a basis for further development research. The research instrument used was a needs analysis questionnaire with 17 questions given to 75 respondents from SMA Negeri 1, SMA Negeri 6, and SMA Negeri 9 Bengkulu. In this study, data analysis used descriptive statistics. Based on the results of the study obtained data that can be concluded that currently, students need the development of learning media based on MOOCs to increase student motivation on temperature and heat material. This study concluded that the development of MOOCs-based learning media to increase students' motivation on the material of temperature and heat is needed in learning. Overall, this research implies that MOOCs-based learning media is needed to increase students' motivation, especially in learning the material of temperature and heat. The implications in learning other materials are highly recommended to be implemented to use the given learning media to gain effectiveness in learning activities, especially in learning the material of temperature and heat.
\end{abstract}

Kata kunci:

Media Pembelajaran;

MOOCs;

Meningkatkan Motivasi

Siswa;

Suhu dan Kalor

\begin{abstract}
Pengembangan media pembelajaran berbasis MOOCs sangat diperlukan dalam meningkatkan motivasi siswa. Penelitian ini bertujuan untuk melakukan analisis kebutuhan pengembangan media pembelajaran berbasis MOOCs untuk meningkatkan motivasi siswa pada materi suhu dan kalor. Jenis penelitian ini merupakan penelitian survei dan studi literatur sebagai dasar dalam penelitian pengembangan selanjutnya. Instrumen penelitian yang digunakan berupa angket analisis kebutuhan dengan 17 butir pertanyaan yang diberikan kepada 75 responden dari siswa pada SMA Negeri 1 Kota Bengkulu, SMA Negeri 6 Kota Bengkulu dan SMA Negeri 9 Kota Bengkulu. Dalam penelitian ini analisis data menggunakan statistik deskriptif. Berdasarkan hasil penelitian diperoleh data yang dapat disimpulkan bahwa saat ini siswa membutuhkan pengembangan media pembelajaran berbasis MOOCs untuk meningkatkan motivasi siswa pada materi suhu dan kalor. Hasil penelitian ini memperoleh kesimpulan bahwa pengembangan media pembelajaran berbasis MOOCs untuk meningkatkan motivasi siswa pada
\end{abstract}

\footnotetext{
${ }^{1}$ PGRI University Palembang, Indonesia

E-mail: drbukmanlian@univpgri-palembang.ac.id

2 Bengkulu University, Indonesia

E-mail: bebbyrinooksatianti@unib.ac.id

3 Bengkulu University, Indonesia

E-mail: eko.risdianto@unib.ac.id

4 Bengkulu University, Indonesia

E-mail: afrizalmayub@unib.ac.id
} 
materi suhu dan kalor sangat dibutuhkan dalam pembelajaran. Implikasi dalam pembelajaran materi lain sangat dianjurkan untuk dilaksanakan sebagai alternatif penggunaan media pembelajaran yang diberikan untuk memperoleh efektifitas dalam kegiatan pembelajaran.

\section{INTRODUCTION}

Permendikbud No. 22 of 2016 concerning learning in primary and secondary education states that the lesson plan is prepared by considering the application of information and communication technology (ICT) in an integrated, systematic, and effective manner according to the situation and conditions. So that maximizing the learning process in the classroom requires learning media that apply ICT (Suwasono \& Puspitasari, 2016).

The role of the media used in learning can liven up the atmosphere of student learning, able to assist students in understanding learning, and as a tool to provide stimulation to students with indicators of increasing student motivation. The presence of media in learning also impacts teaching in presenting information given to students (Nababa, 2016). Student motivation can be influenced by the use of learning media (Ristianti, 2018). Meanwhile, Fathurrochman (2021) concluded that students' learning motivation could be increased using various learning media.

Talking about technological developments is like seeing two sides of a knife where one side provides a positive side, and the other side can also negatively impact. Therefore, we must respond wisely to technological developments, especially in the 4.0 revolution era in education. These changes should be a driving force for the world of education to give birth to creativity to create an educational process that produces (prospective) qualified, professional, and have character (Risdianto, 2019).

Along with the development of information and communication technology, communication as a learning medium can be done using communication media such as computers, e-mail, telephone, internet, and so on. For example, in the education sector, the use of computers has developed as a tool used for administrative matters and as a learning tool (Putri et al., 2019).

The learning system is now booming with distance learning (online). This distance learning also involves the media in conveying knowledge to students and guiding students to learn independently. Distance learning has tough challenges, especially in increasing student motivation. The selection of learning media will be very influential in increasing student learning motivation. It will impact students' understanding of the material presented by the teacher (Fathurrochman, 2021). The characteristics of a distance learning system, according to Keegan (1980), are (1) separation between teacher and learner; (2) the influence of educational institutions/organizations; (3) the use of media that connects teachers and learners; (4) ongoing two-way communication; (5) pay attention to learning as an individual who learns; and (6) education as an industry (Nugroho, 2012).

The current form of distance open education is MOOCs. MOOCs are present as a new model of education and learning, which uses the internet to deliver lecture materials at the world's prestigious universities and educational institutions, creating a kind of revolution. These people are joining together to conduct sustainable courses. MOOCs are the latest hit in online learning and are positioned as an alternative to traditional higher education programs. In line with this phenomenon, MOOCs have also brought a revolution to the education sector in a short period, opening up opportunities for new pedagogies and business models that allow thousands of students to access (Risdianto et al., 2021) freely.

In summary, MOOCs (Massive Open Online Courses) can also be interpreted as online courses that are open and carried out on a large scale with an unlimited number of students. MOOCs are designed to be accessed online by users wherever and whenever students can choose the material they are interested in. The material presented is usually in the form of videos. It is accompanied by downloadable document files containing material that is in accordance with the material taken.

Based on initial observations made at SMA Negeri 9 Bengkulu City, it is known that the teaching materials used by teachers in the learning process are still using printed books and teaching 
materials made by the teachers themselves, such as PowerPoint (PPT). Then for the learning media used only youtube and the classroom. This condition causes learning to be less effective because some students are not enthusiastic about participating in the learning process. Based on these problems, it is necessary to consider what solutions are appropriate and overcome the existing problems. Researchers try to provide recommendations for the development of MOOCs-based learning media. Risdianto et al. (2021) concluded that the development of MOOCs-based learning media is a solution in learning that involves blended learning. However, researchers must first analyze students' needs to develop learning media as tools used in learning.

Therefore, the formulation of the problem from this research is necessary to develop MOOCbased learning media. So based on the formulation of the problem, this research aims to analyze the students' needs to develop learning media based on MOOCs to increase students' motivation on the material of temperature and heat. Researchers must first analyze the students' needs to develop learning media to be used in learning.

\section{METHODS}

The research was carried out at SMA N 1 Bengkulu City, SMA N 6 Bengkulu City and SMA N 9 Bengkulu City in November 2020. The population taken was all students of class XI Science SMA 1, SMA 6, and SMA 9 Bengkulu City, with a sample of 75 students who come from class XI IPA every school. The data collection technique used in this needs analysis research consists of three parts: initial observations of learning, student, needs questionnaires, and literature studies, including mixed learning media, MOOCs, and online learning. The research instruments used in this needs analysis research are observation sheets, student needs questionnaire sheets, and literature related to the development of MOOCs-based learning media to increase student motivation on temperature and heat material. The data analysis technique used is descriptive statistical analysis. Needs analysis is carried out on the data obtained in the form of percentages. The percentage obtained is based on the results of a modified Likert scale calculation. With a Likert scale, the variables to be measured are translated into variable indicators.

Furthermore, these indicators are used as guidelines in compiling question items or statements. As for negative sentences, the score becomes the opposite(Risdianto \& Kusuma, 2016). To calculate the percentage using the formula (Bakri et al., 2015):

$$
\text { Percentage (\%) }=\frac{\Sigma \text { skor perolehan }}{\Sigma \text { skor maksimum }} \times 100 \%
$$

Table 1. Interpretation of Student Response Scores (Sugiyono, 2010)

\begin{tabular}{cc}
\hline Percentage (\%) & Category \\
\hline $0 \%-25 \%$ & Strongly Disagree \\
\hline $26 \%-50 \%$ & Disagree \\
\hline $51 \%-75 \%$ & Agree \\
\hline $76 \%-100 \%$ & Strongly agree \\
\hline
\end{tabular}

\section{FINDINGS AND DISCUSSION}

Based on filling out the needs analysis questionnaire for the development of learning media, a picture of student responses to the teaching materials used in the classroom using three statements that fall into the category of strongly agree, agree and disagree, as shown in table 2.

Table 2. Student Responses to Teaching Materials Used in Class

\begin{tabular}{|c|c|c|}
\hline Statement & Percentage & Category \\
\hline $\begin{array}{l}\text { I need other teaching materials as an } \\
\text { alternative to the currently available } \\
\text { teaching materials }\end{array}$ & $83.00 \%$ & $\begin{array}{l}\text { Strongly } \\
\text { agree }\end{array}$ \\
\hline $\begin{array}{l}\text { The teaching materials used today are less } \\
\text { attractive }\end{array}$ & $53.00 \%$ & Agree \\
\hline
\end{tabular}




\begin{tabular}{lll}
\hline I feel that the currently available teaching & $47.66 \%$ & \\
materials have not been able to make it \\
easier for me to understand physics
\end{tabular}

Based on the data analysis in table 2 above, it was concluded that students' responses to learning using video were shown through 3 statements, all of which fell into the agree and strongly agree on categories as shown in table 3.

Table 3. Students' Responses to Learning Using Video

\begin{tabular}{lcc}
\hline \multicolumn{1}{c}{ Statement } & Percentage & Category \\
\hline $\begin{array}{l}\text { I am interested in learning physics } \\
\text { materials from learning videos on } \\
\text { the internet }\end{array}$ & $73.33 \%$ & Agree \\
\hline $\begin{array}{l}\text { Physics materials presented in the } \\
\text { form of interactive videos are more } \\
\text { interesting than those presented in } \\
\text { textbooks }\end{array}$ & $80.00 \%$ & $\begin{array}{c}\text { Strongly } \\
\text { agree }\end{array}$ \\
\hline $\begin{array}{l}\text { I prefer material that is presented in } \\
\text { the form of videos on the internet }\end{array}$ & $73.66 \%$ & Agree \\
\hline
\end{tabular}

Based on the analysis of the data in table 3 above, it can be concluded that the student's responses to the learning model using video falls into the category of agreeing and strongly agree. This study shows the importance of learning by using video media, which is closely related to the material of temperature and heat.

Table 4. Student Responses to Conventional and Online Learning

\begin{tabular}{lcc}
\hline \multicolumn{1}{c}{ Statement } & Percentage & Category \\
\hline $\begin{array}{l}\text { I need a learning model other than } \\
\text { the conventional learning model }\end{array}$ & $79.33 \%$ & Strongly agree \\
\hline I want online learning & $65.33 \%$ & Agree \\
\hline $\begin{array}{l}\text { I hope for the development of } \\
\text { electronic or online-based learning } \\
\text { such as online learning that can make } \\
\text { it easier for me to learn anywhere and } \\
\text { anytime }\end{array}$ & $77.33 \%$ & Strongly agree \\
\hline $\begin{array}{l}\text { Online learning can increase my } \\
\text { motivation in studying physics }\end{array}$ & $63.66 \%$ & Agree \\
\hline $\begin{array}{l}\text { Online learning allows me to learn on } \\
\text { my own and can repeat the learning }\end{array}$ & $73.66 \%$ & Agree \\
\hline
\end{tabular}

Based on the analysis of the data in table 4 above, it was concluded that student responses to conventional and online learning models fall into the category of agreeing and strongly agree. Conventional and online learning is shown through 5 statements that fall into the agree and strongly agree on categories, as shown in table 4.

The description of students' responses to the development of MOOCs-based learning media is shown through a statement that falls into the category of agreeing to the development of MOOCsbased learning, as shown in table 5 .

Table 5. Student Responses to the Development of MOOCs-Based Learning

\begin{tabular}{ccc}
\hline \multicolumn{1}{c}{ Statement } & Percentage & Category \\
\hline $\begin{array}{l}\text { I want MOOCs-based learning } \\
\text { development }\end{array}$ & $74.33 \%$ & Agree \\
\hline
\end{tabular}

Based on the analysis data obtained from the table above, it is concluded that students agree that the teaching materials available in schools currently have not been able to facilitate students in studying physics, and students expect the development of learning media accompanied by learning videos such as existing videos. On the internet and to meet these needs, students agreed to develop MOOCs-based learning media to increase student motivation in learning. Students are limited to conventional learning in class, but they can also study at home or outside the classroom whenever they want. If as a percentage of the overall answers to each of the indicators in question, it is obtained 
that $70.35 \%$ of students agreed to develop MOOCs-based learning media to increase students' motivation on temperature and heat material.

In addition to using the needs analysis questionnaire data, the results of the research were also obtained by conducting a literature study on previous research related to the topic of research conducted by some of the literature studied as follows: 1) Research conducted by Suyetno et al. (2019) regarding the Development of Massive Open Online Courses (MOOCs) on welding materials. The development developed is proven to be able to support practicum activities. It can be seen from the questionnaires distributed to students. Based on the distributed questionnaires, it was found that the MOOC developed had a high level of feasibility with a percentage of $83.22 \%$. (Suyetno, 2020). 2) Research by Risdianto (2020) on the Response of Early Childhood Education Teachers to Augmented Reality-assisted MOOCs. In this study, based on the analysis conducted on the results of the teacher's response to the MOOCs-assisted augmented reality-based blended learning model provides information that PAUD teachers strongly agree with the blended learning model based on MOOCs and augmented reality, this is indicated by the large percentage obtained by $91.92 \%$ from the maximum percentage of $100 \%$. Furthermore, according to the Likert scale interpretation table for data with a percentage of $76 \%-100 \%$ in the category of strongly agree. So it can be concluded that the quality of the response questionnaire to the needs of this augmented reality-assisted MOOCsbased blended learning model is outstanding (Risdianto et al., 2021). 3) Research by Alhamdi, R., \& Ambiyar, A. (2018) on New Approaches to MOOC Technology as a learning medium in programming courses. Learning programming courses using MOOCs media can be more active in constructing material and knowledge. A new approach to MOOCs technology can be mastered quickly and quickly (Hardi et al., 2018). 4) Research by Johan, RC (2016) on Massive Open Online Courses (MOOCs) in improving the information literacy competence of school librarian teachers. Through the MOOC form, it is obtained an overview of compiling information literacy skills and information packages based on information and communication technology as a form of service in the library learning to be trained in large open online access packages and needs to be carried out and developed (Johan, 2016).

Based on the results of the analysis of several studies above, it was found that the development of MOOCs-based learning media to increase students' motivation on temperature and heat material is very much needed, as evidenced by the perception scores and student responses to the development of MOOCs-based learning media to increase students' motivation on temperature and heat material.

Overall, both from the survey data through questionnaires or literature studies, it is stated that it is necessary to develop MOOCs-based learning media to increase students' motivation on temperature and heat material.

\section{CONCLUSION}

Based on the research that has been done, it can be concluded that the development of MOOCsbased learning media to increase student motivation on temperature and heat material is needed. For further research, it is hoped that more samples will be taken from different schools so that the percentage results obtained are more significant and more accurate.

\section{ACKNOWLEDGEMENTS}

The author would like to thank all students of class XI MIPA SMA Negeri 1 Bengkulu City, SMA Negeri 6 Bengkulu City, and SMA Negeri 9 Bengkulu City who are willing to assist in filling out the needs analysis questionnaire for developing MOOCs-based learning media to increase student motivation on temperature and heat material.

\section{REFERENCES}

Alhamdi, R., \& Ambiyar, A. (2018). Pengaruh Sikap, Norma Subjek dan Kontrol Perilaku Terhadap 
Niat Berwirausaha Mahasiswa di Politeknik Pariwisata Batam. https://journal.universitasmulia.ac.id/index.php/seminastika/article/view/152/

Bahri, S., Sasongko, R. N., Juarsa, O., Djuwita, P., \& Fathurrochman, I. (2021). Zonasi, What, and How. International Journal of Multicultural and Multireligious Understanding, 8(6), 435-444. http://dx.doi.org/10.18415/ijmmu.v8i6.2747

Bakri, F., Rasyid, R., \& Mulyaningsih, R. D. A. (2015). Pengembangan Modul Fisika Berbasis Visual untuk Sekolah Menengah Atas (SMA). Jurnal Penelitian \& Pengembangan Pendidikan Fisika, 01(2), 67-74. https://doi.org/10.21009/1.01211

Fathurrochman, I., Danim, S., Anwar, A. S., \& Kurniah, N. (2021). The School Principals' Role in Education Management at the Regional Level: An Analysis of Educational Policy in the Industrial Revolution 4.0. In International Conference on Educational Sciences and Teacher Profession (ICETeP 2020) (pp. 237-242). Atlantis Press. https://dx.doi.org/10.2991/assehr.k.210227.042

Hardi, R., Gunawan, \& Sumardi. (2018). Pendekatan Baru Teknologi Mooc Sebagai Media Pembelajaran Pada Matakuliah Pemrograman. SNITT- Politeknik Negeri Balikpapan 2018, 317-323.

Johan, R. C. (2016). Massive Open Online Course (MOOC) dalam meningkatkan kompetensi literasi informasi guru pustakawan sekolah. PEDAGOGIA, 13(1), 203-213. https://doi.org/10.17509/pedagogia.v13i1.3382

Nugroho, A. (2012). Pengembangan Model Pembelajaran Jarak Jauh Berbasis Web. Jurnal Transformatika, 9(2), 72. https://doi.org/10.26623/transformatika.v9i2.6o

Putri, R. M., Risdianto, E., \& Rohadi, N. (2019). Pengembangan Media Pembelajaran Interaktif Dengan Menggunakan Adobe Captivate Pada Materi Gerak Harmonik Sederhana. Jurnal Kumparan Fisika, 2(2), 113-120. https://doi.org/10.33369/jkf.2.2.113-120

Risdianto, E. (2019). Analisis Pendidikan Indonesia di Era Revolusi Industri 4 . o Eko Risdianto , M . Cs. Analisis Pendidikan Indonesia Di Era Revolusi Industri 4.o, April, o-16.

Risdianto, E., \& Kusuma, A. B. (2016). Pembuatan Multimedia Interaktif Teknik Operasional Spss 22. $V$, SNF2016-RND-95-SNF2016-RND-102. https://doi.org/10.21009/0305010220

Risdianto, E., Wachidi, W., Riyanto, R., Alexon, A., Fathurrochman, I., \& Kusen, K. (2021). Blended Learning Model Based on Massive Open Online Courses (MOOCs) Assisted by Augmented Reality (BMA) Model as the Electronic Learning Media in the Pandemic Covid-19. AL-ISHLAH: Jurnal Pendidikan, 13(1), 228-241. https://doi.org/10.35445/alishlah.v13i1.470

Risdianto, E., Yanto, M., Kristiawan, M., \& Gunawan, G. (2021). Respon Guru Pendidikan Anak Usia Dini terhadap MOOCs berbantuan Augmented Reality. 5(2), 1487-1500. https://doi.org/10.31004/obsesi.v5i2.907

Ristianti, D. H., Putrajaya, G., \& Fathurrochman, I. (2020). Organizational behavior management through group counseling discussions as a radicalism preventive effort. Jurnal Konseling dan Pendidikan, 8(1), 23-31. https://doi.org/10.29210/139900

Sugiyono. (2010). Metode Penelitian Pendidikan (Pendekatan Kuantitatif, Kualitatif, dan R\&D. Alfabeta.

Suryanto, H., Sahana, R. T., Aminnudin, Suyetno, A., Widiyanti, \& Yanuhar, U. (2019). Effect of carrageenan on the structure of cassava starch bioplastic after extrusion process. In AIP Conference Proceedings (Vol. 2120, No. 1, p. 080023). AIP Publishing LLC. https://doi.org/10.1063/1.5115761

Suwasono, P., \& Puspitasari, E. (2016). Pengaruh Problem Based Learning Berbantuan ICT terhadap Kemampuan Pemecahan Masalah Mahasiswa Pendidikan Fisika Angkatan Tahun 2016 / 2017 pada Materi Fluida Statis. Jurnal Riset Pendidikan Fisika, 1(1), 28-32.

Suyetno, A. (2020). Pengembangan Massive Open Online Courses (MOOCs) pada Materi Pengelasan. Jurnal Teknik Mesin Dan Pembelajaran, 2(2), 141. https://doi.org/10.17977/umo54v2i2p141-152 